For citation: Malatinec T. (2019). Attitudes of Europeans towards Green Products. Ekonomika Regiona [Economy of Region], 15(1), 99-106

doi 10.17059/2019-1-8

UDC: 332,339

JEL: Q58, H70

T. Malatinec

Technical University of Košice (Košice, Slovakia; e-mail: tomas.malatinec@tuke.sk)

\title{
ATTITUDES OF EUROPEANS TOWARDS GREEN PRODUCTS
}

Currently, green production is becoming more important than ever before. Reasons are obvious without being specifically mentioned. Policy makers support various tools to encourage individuals and entities of using green products. Green public procurement (GPP) is a tool intended to support the achievement of environmental goals through the green purchasing. However, there is still scope for better use of GPP. What do policy makers need to know to propose an efficient intervention to stimulate the use of green products? An analysis of individual attitudes towards green products is particularly interesting in designing effective public interventions. The conclusions drawn from the literature review lead me to formulate the following research questions. What attitudes have Europeans towards green products? Which characteristics of individual influence his positive attitudes towards green products? I used the Open Data Barometer from 2012 and ordered logit models to identify statistically significant characteristics of individuals, which they use to determine their attitudes towards green products. Based on the results, I estimate who has a higher odds of having a positive attitude towards green products and therefore is predisposed to use them. Gender seems to be statistically significant predictor of more positive attitudes towards green products. Women have higher odds to have more positive attitudes comparing to men. Moreover, individual attitudes towards green products are determined by age, municipality size and working aspects. The results may be considered when making tailor-made interventions to support GPP and environmentally friendly production. This can be of interest to policy makers at regional or local level.

Keywords: green public procurement, green purchasing, green products, attitudes, perception, environment, European Union, public interventions, public policy, local and regional self-governments

\section{Introduction}

Nowadays, greater attention is paid to the green production. The topic has become part of the working agenda of the institutions at national, European as well as international level. Public institutions play a significant role in the use and promotion of green products. For example, green public procurement is a modern soft tool intended to support achievement of environmental goals within the public administration. In the European Union, it is a voluntary tool governed by the European Union law. Strengthening of its commitment can be expected in the future. Based on the Europeanisation, national policies of the EU member states are gradually becoming more unified [1]. Green public procurement is a tool used in the public administration, which is considered to be a major consumer of goods and services in the European Union. There are several ways to implement green public procurement. One way is e.g. through the use of environmental performance clauses in the contracts [2]. Green public procurement requires the inclusion of clear

\footnotetext{
1 (c) Malatinec T. Text. 2019.
}

and verifiable environmental criteria for products and services in the public procurement process. The European Commission and a number of European countries have developed and updated guidance in this area. "The challenge of furthering take-up by more public sector bodies so that green public procurement becomes common practice still remains" ${ }^{2}$. Incorporation of environmental criteria into public purchases leads to support for development of green products and practices, green innovation and to sustainable development. Scientific and grey literature often deals with the measures, which really impact f green public contracts and contribute to sustainable development. Despite that fact, a lack of information, knowledge, skills and competences among public procurers still remains [3]. In the recent years an increasing number of scientific articles have been published on green public procurement issues [4]. For academics, there are several interesting questions to be analysed. One of them is: What do policy makers need to know to propose an efficient

\footnotetext{
${ }^{2}$ European Commission. (2018a). Green public procurement [Electronic source]. Retrieved from http://ec.europa.eu/environment/gpp/index_en.htm (Date of access: 20.08.2018).
} 
intervention to stimulate the use of green public procurement and thus promote green production? Scientific and grey literature partially addresses e.g. the issue of attitudes on an individual level by giving priority to green practices and green products. A personal attitude to develop, produce, promote or the use green products is a significant aspect, especially at the time of voluntary use of green public procurement in public administration. Individual attitudes may affect for instance the use of green products and green practices mainly in regional and local self-governments which are largely independent in shaping their own environmental policy. The use of soft environmental tools often depends on decision of individuals and in particular public representatives, which can be determined by their own attitudes towards green products. A subsequent interesting question is: Which characteristics of individuals (potentially those who may promote or benefit from green public procurement and green products) are determining their attitude towards green products. Gender, age, education, and other characteristics may be taken into account when analysing personal attitudes.

The paper focuses on assessing an individual attitude of Europeans towards green products and identifying the characteristics that determine a more positive perception of green products on an individual level. The results can be taken into account when proposing tailor-made public interventions target on public representatives or the general public to support green economy or use of green public procurement at regional and local level.

\section{Theoretical Background}

Issues of green production and environmentally-friendly products are currently rapidly growing in importance [5]. "There is growing pressure on business entities to demonstrate that the way in which they are producing is environmentally friendly" ${ }^{1}$. They are constantly encouraged offer more and more environmentally friendly products. Green production has become "a stable requirement for sustainable development and a niche for competition for modern business entities" [6]. It is based on the principles of environmental protection targeting in particular to reduce industrial waste, save energy and scarce resources, and minimize pollution to natural environment, but all this while achieving desired

\footnotetext{
${ }^{1}$ European Commission. (2012). Building the Single Market for Green Products: Facilitating better and credible information on environmental performance of products and organisations. Impact Assessment Report, 46 p., Brussels, Belgium.
}

production economy [6]. Considerable number of businesses entities has already started to implement important activities towards green growth. In detail it means that they have ensured their development is economically and environmentally sustainable $^{2}$. Sustainable development has since long been also the pillar of the European integration and it is governed in the EU Treaties and other legal acts. The European Union gives recognition to sustainable development "economic, social and environmental dimensions that should be tackled together. Development must meet the needs of the present without compromising the ability of future generations to meet their own needs. A life of dignity for all within the planet's limits and reconciling economic efficiency, social inclusion and environmental responsibility is at the essence of sustainable development" ${ }^{3}$. OECD countries have also used their environmental policies to promote sustainable production and environmentally friendly innovation. However, this is done without building of necessary coherence and synergies with other thematic policies. That is why environmental goals have started to be integrated in innovation policies. This is much recommended to help achieve environmental and socio-economic goals simultaneously. ${ }^{4}$

Green product is in general known as an ecological product or environmentally friendly product. A green product is supposed to reduce the impact of its consumption on the environment. This can be achieved, for example, through "the use of making-processes, components and recycling techniques which are less harm for the natural environment than those of conventional products" [7]. Green products can be an opportunity for business entities. Companies can benefit from green production by "reducing long-term liabilities, reducing regulatory costs, pre-empting regulation, reducing supply chain risk, improving internal efficiencies, enhancing market opportunities" [8]. However, companies face non-uniform rules in EU member countries. This consequently limits the availability of green products that could be used in green public procurement. It also results in additional costs for business entities and confusion for

\footnotetext{
2 OECD. (2011). OECD Sustainable Manufacturing Toolkit. 54 p. [Electronic source]. Retrieved from http://www.oecd. org/innovation/green/toolkit/48704993.pdf (Date of access: 05.09.2018).

${ }^{3}$ European Commission. (2018b). Sustainable development [Electronic source]. Retrieved from http://ec.europa.eu/environment/sustainable-development/index_en.htm (Date of access: 20.08 .2018$)$.

${ }^{4}$ OECD. (2009). Eco-innovation in Industry: enabling green growth. OECD, 276 p. ISBN 978-92-64-07721-8.
} 
potential consumers ${ }^{1}$. Ecolabels indicating environmental friendly products are nowadays becoming increasingly popular as an important signal of environmental quality and attitudes towards environment protection [9].

Better understanding consumer behaviour, perception and attitudes is therefore a core tool to efficient implementation of new environmental initiatives. ${ }^{2}$ "Placement of the green products in the store can create awareness for green conscious consumers' to have better options for them to purchase the products. The awareness and willingness of consumers to purchase the green products differ from one country to another" [8]. As already mentioned, the largest share of the purchasing power in the European Union market is represented by public institutions. There is a lot of interest of the European Commission that the public funds spent across the European Union are directed towards achieving environmental goals and contribute to the prevention of environmental pollution. ${ }^{3}$ Green public procurement is mainly promoted at European level. Green public procurement policy is focused on tackling a number of environmental challenges, climate change, and non-economic use of primary resources, deforestation, air pollution, water, soil, waste generation and packaging waste. The environmental characteristics that can be included in the tender documents are aimed at reducing the negative impact of products on the environment. ${ }^{4}$ An effective green public procurement system can make a significant contribution to protecting nature and combating climate change. ${ }^{5}$ Green public procure-

\footnotetext{
${ }^{1}$ European Commission. (2017). Single market for green products initiative [Electronic source]. Retrieved from http://ec.europa.eu/environment/ eussd/smgp/index.htm. (Date of access: 10.08.2018).

${ }^{2}$ European Commission. (2013). Attitudes of Europeans towards Building the Single Market for Green Products: report. 174 p. [Electronic source]. Retrieved from http://ec.europa.eu/ commfrontoffice/publicopinion/flash/fl_367_en.pdf (Date of access: 10.08.2018).

${ }^{3}$ Government Office of the Slovak Republic. (2015). National action plan for green public procurement in Slovakia 20162020 [Electronic source]. Retrieved from http://www.rokovania.sk/File.aspx/ViewDocumentHtml/Mater-Dokum205132? prefixFile $=\mathrm{m}$ (Date of access: 20.08.2018).

4 Slovak Environmental Agency. (2014). Green Public Procurement. 42 p. Bratislava, Slovakia. ISBN 978-80-89503-34-6.

${ }^{5}$ Ministry of Environment of the Slovak Republic. (2018). How protect environment and money through the green public procurement [Electronic source]. Retrieved from https://www. minzp.sk/files/iep/2018_01_zelene_verejne_obstaravanie.pdf (Date of access: 02.09.2018).
}

ment offers a large potential as an instrument for creating environmental added value $[10,11]$.

Green public procurement involves the purchase of goods and services that meet stringent conditions for energy consumption (laptops), the amount of emissions produced (cars), or the origin of raw materials (paper). The European Commission sets criteria for "greenness" for different product groups. Account is taken not only of the cost of procurement of goods and services, but also of operation (e.g. fuel, electricity) or disposal of products at the end of their life cycle. Promoting green business gives new incentives for the development of eco-technologies and innovative solutions.11 Green public procurement is one of the voluntary instruments of environmental policy, which means that it is neither enforceable by law, nor motivated by any form of incentive, and its non-application is not punishable. That is why personal attitudes play a big role in the desire to use green products. At the same time, it is a preventive strategy tool implemented in the form of measures to prevent environmental pollution.9 Environmental labelling promotes the production and consumption of products that are more environmentally friendly throughout their lifecycle and which provide customers with accurate, non-intrusive and scientifically-based information on the impact of products on the environment. ${ }^{6}$ Some products have environmental labels to allow consumers to choose those that have been recognized as less harmful to the environment. This is also a voluntary scheme, based on specific scientific environmental criteria, in a transparent and non-discriminatory way for all businesses. Consumers and suppliers can easily identify products that are environmentally friendly. Environmental labelling is one of the voluntary environmental policy instruments10. Based on it, they can make a decision whether to use green products or not. The decision can again be affected by individual attitudes towards green products. This statement supports our analysis.

\section{Data and Methodology}

Based on the conclusions drawn from the scientific and grey literature review we devote our attention to two research questions:

1. What attitude have Europeans towards green products?

\footnotetext{
${ }^{6}$ Enviroportal. (2018). Environmental labelling of products. [Electronic source] Retrieved from https://www.enviroportal. sk/indicator/detail?id=1221 (Date of access: 02.09.2018).
} 
2. Which characteristics of the respondents influence the positive attitudes towards green products?

We used the Open Data Barometer. The unique data are collected on the basis of the questionnaire survey conducted in 2012. Sample of respondents covers whole territory of the European Union (current $28 \mathrm{EU}$ members states). The data set contains 26573 records in total. Questions are selected to assess attitudes of Europeans towards green products.

Selected survey questions:

- Rank the importance of the product's impact on the environment when making decision on what products to buy. $\left(Q_{1}-\right.$ model $\left.M 1\right)$

scale: very important (1), fairy important (2), not very important (3), not at all important (4)

- Rank statement: environmentally-friendly products are good value for money. $\left(Q_{2}-\right.$ model M2)

scale: strongly agree (1), tend to agree (2), tend to disagree (3), strongly disagree (4)

- Rank statement: using environmentally-friendly products is "the right thing to do". $\left(Q_{3}\right.$ - model M3)

scale: strongly agree (1), tend to agree (2), tend to disagree (3), strongly disagree (4)

The survey contains general questions about the characteristics of the respondents in order to identify the different types of respondents - that is, with higher or lower odds to have positive attitudes towards green products. The characteristics of respondents include four general categories: gender, age, type of work (working aspects) and size of municipality they are living. It is important that gender and age be included in the set of independent variables as this allows assessing how gender and age differences influence personnel attitudes towards green products. We suppose that there are differences between generations in their attitudes towards green products. Size of municipality seems to be interesting factor in order to find statistically significant differences in the attitudes of respondents form urban area and rural area. Working aspects relating to types of work or types of employment may also determine personnel attitudes towards green production. There may be also differences regarding this factor. Scope for processing of others factors still remains and the survey can be extended in the future.

In order to find this out, we run generalized models of logistic regression of ordinal type (outcome variable is ordinal). The general formula of logistic regression can be expressed as follows:

$$
\begin{gathered}
\log i t(p)=\log \left(\frac{p}{1-p}\right)= \\
=\beta_{0}+\beta_{1} X_{1}+\beta_{2} X_{2}+\ldots+\beta_{k} X_{k},
\end{gathered}
$$

where, $p$ is the probability that the dependent variable will acquire a value of 1 and $\beta_{k}$ are unknown regression coefficients, that are to be estimated in each model. The formulas of three logistic regressions are:

$$
\begin{gathered}
p\left(Y_{M 1 / M 2 / M 3}\right)= \\
=F\left(\beta_{0}+\beta_{1} S E X+\beta_{2} A G E+\beta_{3} W O R K+\beta_{4} L I V\right) .
\end{gathered}
$$

In the econometrics models the $\mathrm{Y}$ (dependent variable) is the ranking of the importance of the product's impact on the environment when making a decision on what products to buy (model $M 1$ ), the ranking of statement that environmentally-friendly products are good value for money (model M2) and the ranking of feeling that using environmentally-friendly products is "the right thing to do" (model M3). As already mentioned, ranking was conducted through the Likert scale, while the reference value is the most positive attitude: very important/strongly agree - (1). The $X$ represents the vector of explanatory (independent) variables used in the models. Data were analysed using the statistical package IBM SPSS Statistics 19. The Omnibus test has been applied to test quality of the models. Estimation of comparative quality comparison of individual econometric models among themselves is realized, for example, through the Akaike information criterion (AIC):

$$
A I C=-2 l+2 p,
$$

where, $l=$ Log-likelihood of model, $p=$ number of parameters in the model.

Our study is limited to the selected questions from the Open Data Barometer 2012. It is presumed that green public procurement is still not well known concept between local self-governments in the European Union. Aggregate data specifically geared to attitudes of public administrators towards green products or green initiatives are missing, therefore we focus on available source of information.

\section{Results and Discussion}

European level is used because a significant part of the interventions is proposed and implemented by the European Union. The member states are encourage to harmonize their legal frameworks and implement environmentally friendly measures. There is a general belief among scientists, academics and environmental activists that through green purchasing that means for 
Descriptive statistics of the respondents sample

\begin{tabular}{|c|c|c|c|c|}
\hline \multicolumn{2}{|r|}{ CHARACTERISTICS } & CODE & FREQUENCY & SHARE, \% \\
\hline \multirow{2}{*}{$\operatorname{sex}(S E X)$} & male & 1 & 14829 & 58,8 \\
\hline & female & 2 & 10380 & 41,2 \\
\hline \multirow{4}{*}{ age $(A G E)$} & $15-24$ & 1 & 2141 & 8,5 \\
\hline & $25-39$ & 2 & 4919 & 19,5 \\
\hline & $40-54$ & 3 & 6869 & 27,3 \\
\hline & $55+$ & 4 & 11280 & 44,7 \\
\hline \multirow{3}{*}{$\begin{array}{c}\text { size of } \\
\text { municipality } \\
(L I V)\end{array}$} & living in rural area or village & 1 & 8229 & 32,6 \\
\hline & living in small and middle sized town & 2 & 9359 & 37,1 \\
\hline & living in large town & 3 & 7521 & 29,8 \\
\hline \multirow{4}{*}{ work $(W O R K)$} & self-employed & 1 & 2527 & 10,0 \\
\hline & employee & 2 & 8060 & 32,0 \\
\hline & manual worker & 3 & 1869 & 7,4 \\
\hline & not working & 4 & 12753 & 50,6 \\
\hline
\end{tabular}

Source: own processing, 2018.

Selection based on the Open Data Barometer from 2012.

Descriptive statistics of the respondents answers

\begin{tabular}{|c|c|c|c|c|c|}
\hline \multicolumn{6}{|c|}{ QUESTIONS } \\
\hline \multicolumn{2}{|c|}{$Q_{1}$} & \multicolumn{2}{|c|}{$Q_{2}$} & \multicolumn{2}{|c|}{$Q_{3}$} \\
\hline \multicolumn{2}{|c|}{$\begin{array}{l}\text { The importance of the product's impact on } \\
\text { the environment when making decision on } \\
\text { what products to buy }\end{array}$} & \multicolumn{2}{|c|}{$\begin{array}{l}\text { Environmentally-friendly products } \\
\text { are good value for money }\end{array}$} & \multicolumn{2}{|c|}{$\begin{array}{l}\text { Using environmentally-friendly } \\
\text { products is "the right thing to do" }\end{array}$} \\
\hline SCALE & FREQUENCY, \% & SCALE & FREQUENCY, \% & SCALE & FREQUENCY, \% \\
\hline very important & 38,8 & strongly agree & 20,5 & strongly agree & 67,4 \\
\hline fairy important & 44,3 & tend to agree & 41,5 & tend to agree & 28,0 \\
\hline not very important & 12,2 & tend to disagree & 25,1 & tend to disagree & 2,8 \\
\hline not at all important & 2,7 & strongly disagree & 7,2 & strongly disagree & 1,2 \\
\hline no answer & 2,0 & no answer & 5,7 & no answer & 0,6 \\
\hline
\end{tabular}

Source: own processing, 2018.

Selection based on the Open Data Barometer from 2012.

example products with recyclable packaging or properly disposing of non-biodegradable garbage, consumers (mainly public authorities) can contribute significantly to improve the quality of the environment [12].

Public institutions play important role in promotion of development, production and consumption support of green products. Green public procurement is recommended as main tool with expected impact on supply and demand for green products. However, attitudes of individuals are still very important aspects that can determine a final decision to use or do not use green products. Even the most promising promotional tools to support green products are becoming ineffective if they target the wrong target group. Therefore, tailor-made interventions can be made based on the results of analyses that point to individual preferences in relation to green products. Results listed in Table 1, Table 2 and Table 3 were obtained based on the proposed methodology and the Open Data
Barometer from 2012. Table 1 contains descriptive statistics of the respondents' sample and Table 2 descriptive statistics of Europeans attitudes towards green products.

Based on the logistic regression results listed in the Table 3, the following findings can be mentioned. Women have statistically significant higher odds to rank the importance of the product's impact on the environment when making decision on what products to buy as very important compared to men. Respondents aged 25 years and over have also statistically significant higher odds when comparing to the respondents aged between 15 and 24 years. The odds are higher depending on the age category to which they belong. The results show that respondents living in large cities have statistically significant lower odds to rank the importance of the product's impact on the environment when making decision on what products to buy as very important compared to the respondents living in rural areas or villages. Employee has 
Table 3

Parameter estimates for the econometric models in the field of Europeans attitudes towards green products

\begin{tabular}{|c|c|c|c|c|c|c|c|c|c|c|}
\hline & & \multicolumn{3}{|c|}{$M_{1}$} & \multicolumn{3}{|c|}{$M_{2}$} & \multicolumn{3}{|c|}{$M_{3}$} \\
\hline & Ref. & B & $\operatorname{EXP}(B)$ & SIG. & B & $\operatorname{EXP}(B)$ & SIG. & B & $\operatorname{EXP}(B)$ & SIG. \\
\hline$[$ Sex $=$ female $]$ & - & $(+)$ & 1,494 & $* * *$ & $(+)$ & 1,101 & $* * *$ & $(+)$ & 1,216 & $* * *$ \\
\hline$[$ Sex $=$ male $]$ & 0 & & 1,000 & & & 1,000 & & & 1,000 & \\
\hline$[$ Age $=55+]$ & - & $(+)$ & 2,461 & $* * *$ & $(+)$ & 1,054 & & $(+)$ & 1,203 & $* * *$ \\
\hline$[$ Age $=40-54]$ & - & $(+)$ & 2,147 & $* * *$ & $(-)$ & 0,944 & & $(+)$ & 1,164 & $* * *$ \\
\hline$[$ Age $=25-39]$ & - & $(+)$ & 1,575 & $* * *$ & $(-)$ & 0,947 & & $(+)$ & 1,198 & $* * *$ \\
\hline$[$ Age $=15-24]$ & 0 & & 1,000 & & & 1,000 & & & 1,000 & \\
\hline [Living in large town ] & - & $(-)$ & 0,942 & ** & $(-)$ & 0,970 & & $(+)$ & 1,165 & *** \\
\hline $\begin{array}{l}\text { [Living in small/middle sized } \\
\text { town] }\end{array}$ & - & $(+)$ & 1,000 & & $(+)$ & 1,006 & & $(+)$ & 1,043 & \\
\hline [Living in rural area or village] & 0 & & 1,000 & & & 1,000 & & & 1,000 & \\
\hline [Work = not working] & - & $(+)$ & 1,064 & & $(+)$ & 1,342 & $* * *$ & $(-)$ & 0,969 & \\
\hline [Work = manual worker] & - & $(-)$ & 0,904 & * & $(+)$ & 1,549 & *** & $(-)$ & 0,763 & *** \\
\hline [Work = employee] & - & $(-)$ & 0,830 & *** & $(+)$ & 1,118 & $* * *$ & $(-)$ & 0,922 & * \\
\hline [Work = self-employed] & 0 & & 1,000 & & & 1,000 & & & 1,000 & \\
\hline Total & & & \multicolumn{2}{|c|}{26476} & & \multicolumn{2}{|c|}{25209} & & \multicolumn{2}{|c|}{25209} \\
\hline AIC & & \multicolumn{3}{|c|}{2582,503} & \multicolumn{3}{|c|}{2561,918} & \multicolumn{3}{|c|}{1760,682} \\
\hline Omnibus test & & & & *** & & & *** & & & $* * *$ \\
\hline
\end{tabular}

Significance levels: ${ }^{* *}$ for $\mathrm{p}<0,01 ;{ }^{* *}$ for $0,01 \leq \mathrm{p}<0,05 ;{ }^{*}$ for $0,05 \leq \mathrm{p}<0,1$.

Source: own processing 2018.

statistically lower odds to rank the importance of the product's impact on the environment when making decision on what products to buy as very important compared to self-employed respondent.

Women have statistically significant higher odds strongly agree with the statement that environmentally-friendly products are good value for money compared to men. Not working respondents, manual workers and employees have statistically significant higher odds strongly agree with the stamen mentioned above when comparing to self-employed respondents. Age and municipality size seems to be statistically not significant.

Women have statistically significant higher odds strongly agree with the statement that environmentally-friendly products are good value for money compared to men. Not working respondents, manual workers and employees have statistically significant higher odds strongly agree with the stamen mentioned above when comparing to self-employed respondents. Age and municipality size seems to be statistically not significant. Women have also statistically significant higher odds strongly agree that using environmentally-friendly products is "the right thing to do" compared to men. Respondents aged 25 years and over have statistically significant higher odds compared to respondents aged between 15 and 24 years. The odds are again higher depending on the age category to which they belong. Respondents living in large cities have also statistically signif- icant higher odds strongly agree that using environmentally-friendly products is "the right thing to do" compared to respondents living in rural areas or villages. On the other hand, manual workers and employees have statistically significant lower odds strongly agree with this statement comparing to self-employed respondents.

The results clearly show that mainly gender can be included among the respondents' characteristics which determine individual attitudes towards green products. This is supported also by this result presented in other studies and the result indicated that there is no difference between gender in their environmental attitudes and their attitudes on green products [13]. But individual attitudes towards green products are also determined by age, municipality size and working aspects.

A thematic similar survey was also carried out in Slovakia [e.g. 14]. The results showed that consumers perceive green products mainly through their positive impacts on environment. Recyclability is a very important feature of the green product. However, the local results do not point to statistically significance of gender when analysing respondents' preferences [14]. Consumer education about the environment is crucial for consumers to form a more favourable mind-set towards environmentally friendly products. Communication initiatives that highlight various environmental support campaigns and environmentally conscious product strategies are some of the ways to encourage pur- 
chasing behaviour [15]. Education of procurement staff is also required to ensure benefits of green public procurement [16]. Literature also confirms that central governments should develop training mechanism to spread information on green production and benefits of green purchasing [17 - 19]. Testa et al. [6] have also confirmed that policy tools to support green public procurement are slowly starting to work in practice but they still need to be supported by specific and tailor-made actions at different levels (EU, national, regional and local). This can be done by focusing on individuals' attitudes and preferences towards green products. Authors Petrescu, Oncioiu and Petrescu [20] have conducted survey and the results indicate that a more positive attitude of consumers towards green production will further strengthen their purchasing interest. Green awareness is confirmed as important factor that can determine choice to purchase green products also in other studies, e.g. [21, 22]. Authors Nikolaou and Loizou [23] have concluded that governmental initiatives to strengthen consumer preferences for green products might be necessary. Popularization of green production requires guidance from the national, regional or local governments [24]. Because consumers have shown an increasing interest for green products over the past decades [25], potential of green public procurement can be used to a greater extent at local and regional level. The paper offers the results of individuals attitudes analysis based on the available data. This can be of interest to policy makers at regional and local level who are trying to set up public tools to support environmental policy and promote environmentally friendly production and consumption in the most effective way.

\section{Conclusion}

In this paper, attitudes of Europeans towards green products are examined. Results are relevant for policy makers to support current green initiatives in public administration. Green public procurement is a tool that is increasingly being promoted in public administration. Green public procurement is strongly supported by the European Union. However, in many EU member states, despite the current awareness and dissemination of information on the benefits of green public procurement, there is still a great potential for better use. What kind of interventions should be made to support the implementation of green purchasing and using of green products? Who is the target group of green products? Scientific literature offers partial results of studies that analyse public attitudes and individuals' perception on green production. The aim of this article was to contribute to scientific and academic debate and identify the characteristics of respondents that determine their individual attitude towards green products. In order to achieve the results, I used the Open Data Barometer 2012 and run econometric models. The results point to statistically significant characteristics of respondents that can help to identify which respondent has a more positive attitude towards green products. Gender seems to be statistically significant predictor of more positive attitudes towards green products. Women have higher odds to have positive attitudes comparing to men. But individual attitudes towards green products are equally determined by age, municipality size and working aspects. Results may be considered by public decision makers and policy makers mainly at regional and local levels when designing public policies to support green economy and environmentally friendly production. Futhermore, national tier of public administration and central public bodies can consider these findings when encouraging their subordinate organisations to use green public procurement.

\section{Acknowledgement}

This research has been supported by the Scientific Grant Agency of the Ministry of Education, Science, Research and Sport of the SR and the Slovak Academy of Sciences VEGA - project VEGA 1/0750/17 Perspectives of GPP (Green Public Procurement) in public procurement at regional and local level.

\section{References}

1. Malatinec, T. (2017). Legislative framework of green public procurement and Europeanisation of the Slovak practice. Juridical Tribune, 7 (Special), 95-107.

2. Piga, G. and Tatrai, T. (2016). Public procurement policy, Routledge, 229. ISBN 978-1-138-92150-4.

3. Testa, F., Grappio, P., Gusmerotti, N., Iraldo, F., Frey, M. (2016). Examining green public procurement using content analysis: existing difficulties for procurers and useful recommendations. Environment, Development and Sustainability, 18 (1), 197-219. doi: 10.1007/s10668-015-9634-1.

4. Cheng, W., Appolloni, A., D’Amato, A., Zhu, Q. (2018). Green Public Procurement, missing concepts and future trends - A critical review. Journal of Cleaner Production, 176, 770-784. doi: 10.1016/j.jclepro.2017.12.027.

5. Baines, T., Brown, S., Benedettini, O., \& Ball, P. (2012). Examining green production and its role within the competitive strategy of manufacturers. Journal of Industrial Engineering and Management, 5 (1), 53-87. doi: 10.3926/jiem.405. 
6. Ming, Z., Yanchun P., Zhimin Ch., \& Wei Y. (2013) Optimizing green production strategies: An integrated approach. Computers \& Industrial Engineering, 65(3), 517-528. doi: 10.1016/j.cie.2013.02.020.

7. Morel, M. and Kwakye, F. (2012). Green marketing: consumers' attitudes towards eco-friendly products and purchase intention in the fast moving consumer goods (FMCG) sector, 98. [Electronic source] Retrieved from http://www.diva-portal. org/smash/get/diva2:553342/fulltext01 (Date of access: 25.08.2018).

8. Darnall, N. (2008). What the federal government can do to encourage green production, 41. [Electronic source] Retrieved from http://observgo.uquebec.ca/observgo/fichiers/48461_PSEC-30.pdf (Date of access: 25.08.2018).

9. Malatinec, T., Kováč, V. (2017). Procuring green products - who, what and where. Conference proceeding. Central European Conference in Regional Science, Banská Bysdtrica, 540-547. ISBN 978-80-557-1335-9.

10. Peuckert, J., Quitzow, R. (2017). Acceptance of bio-based products in the business-to-business market and public procurement: Expert survey results. Biofuels, Bioprod. Bioref., 11, 92-109. doi:10.1002/bbb.1725.

11. Aldenius, M., Khan, J. (2017). Strategic use of green public procurement in the bus sector: Challenges and opportunities. Journal of Cleaner Production, 164, 250-257. doi: 10.1016/j.jclepro.2017.06.196.

12. Abdul-Muhmin, A. G. (2007). Exploring consumers' willingness to be environmentally friendly. International Journal of Consumer Studies, 31, 237-247.

13. Tan hen Booi, Ch. - Teck-Chai, L. (2010). Attitude towards the environment and green products: consumers' perspective. Management Science and Engineering, 4(2), 27-39. ISSN 1913-0341.

14. Malá, D. - Sedliačiková, M. (2018). Green product. In: The Influence of Innovative Marketing Concepts on the Behaviour of Chosen Market Subjects in Slovakia: Proceedings of Scientific Papers. Banská Bystrica, Slovakia, 218. ISBN 978-80-557-1346-5.

15. Cheah, I. \& I. Phau.(2011). Attitudes towards environmentally friendly products: The influence of eco-literacy, interpersonal influence and value orientation. Marketing Intelligence \& Planning, 29(5), 452-472. doi: 10.1108/02634501111153674.

16. Xu S., Chu C., Ju M., Shao C. (2016). System Establishment and Method Application for Quantitatively Evaluating the Green Degree of the Products in Green Public Procurement. Sustainability, 8(9), 941. doi: 10.3390/su8090941.

17. Liu, J., Shi, B., Xue, J., Wang, Q. (2018). Improving the green public procurement performance of Chinese local governments: From the perspective of officials' knowledge. Journal of Purchasing and Supply Management, Article in Press. ISSN 1478-4092. doi: 10.1016/j.pursup.2018.05.002.

18. Michelsen, O., de Boer, L. (2009). Green procurement in Norway; a survey of practices at the municipal and county level. Journal of Environmental Management, 91(1), 160-167. doi: 10.1016/j.jenvman.2009.08.001.

19. Testa, F., Annunziata, E., Iraldo, F., Frey, M. (2014). Drawbacks and opportunities of green public procurement: an effective tool for sustainable production. Journal of Cleaner Production, 112(3), 1893-1900. doi: 10.1016/j.jclepro.2014.09.092.

20. Petrescu, A. G., Oncioiu, I., Petrescu, M. (2017). Perception of Organic Food Consumption in Romania. Foods, 6(6). doi: $10.3390 /$ foods6060042.

21. Sarmiento, C. V., El Hanandeh, A. (2018). Customers' perceptions and expectations of environmentally sustainable restaurant and the development of green index: The case of the Gold Coast, Australia. Sustainable Production and Consumption, 15, 16-24. doi: 10.1016/j.spc.2018.04.001.

22. Chekima, B., Wafa, S. A. W. S. K., Igau, O. A., Chekima, S., Sondoh, S. L. (2016). Examining green consumerism motivational drivers: does premium price and demographics matter to green purchasing? Journal of Cleaner Production, 112, 3436-3450. doi: 10.1016/j.jclepro.2015.09.102.

23. Nikolaou, I. E., Loizou, C. (2014). The Green Public Procurement in the midst of the economic crisis: is it a suitable policy tool? Journal of Integrative Environmental Sciences, 12(1), 49-66. doi: 10.1080/1943815X.2014.993657.

24. Xu, S., Chu, Ch., Zhang, Y., Ye, D., Wang, Y., Ju, M. (2018). Entangled stakeholder roles and perceptions of sustainable consumption: An evaluation of sustainable consumption practices in Tianjin, China. Journal of Environmental Management, 223, 841-848. doi: 10.1016/j.jenvman.2018.07.007.

25. Dangelico, R. M., Vocalelli, D. (2017). "Green Marketing": An analysis of definitions, strategy steps, and tools through a systematic review of the literature. Journal of Cleaner Production, 165, 1263-1279. doi: 10.1016/j.jclepro.2017.07.184.

\section{Author}

Tomáš Malatinec - Doctor of Public Administration and Regional Development, Assistant Professor, Department of Regional Science and Management, Technical University of Košice; Author Scopus ID: 55574329200 (32, Němcovej, 040 11, Košice, Slovakia; e-mail: tomas.malatinec@tuke.sk). 